\title{
ON THE DETERMINANTS OF RETURN ON EQUITY IN SOUTH AFRICA'S FINANCIAL SERVICES INDUSTRY
}

\author{
Chiedza Ndlovu* \\ University of Witwatersrand \\ chiedza.ndlovu@students.wits.ac.za
}

Received: September 2014

\author{
Paul Alagidede" \\ University of the Witwatersrand \\ paul.alagidede@wits.ac.za
}

Accepted: January 2015

\begin{abstract}
This study examines the factors that determine the return on equity (ROE) of financial companies listed on the Johannesburg Securities Exchange (JSE). Two empirical strategies were adopted: the DuPont model and a multifactor Arbitrage Pricing Theory (APT). Using the financial data of 73 companies and macro-economic indicators from 2002 to 2012, the study found that there was a positive relationship between profit margin and ROE, which can be enhanced if managers employ cost leadership strategies. Companies with predictable cash flows can afford high levels of debt and therefore high ROE, while companies characterised by unpredictable market conditions should use debt with caution. We found a positive relationship between interest rates and ROE for banks, insurance and real estate companies, which may suggest that managers employ short-term duration gap strategies in managing assets and liabilities mismatch rather than relying on long-term strategies. Inflation for banks, insurance and real estate companies is inversely related to ROE, and financial firms are better off immunising their portfolios against revenue erosion.
\end{abstract}

Keywords

DuPont Model, Johannesburg Securities Exchange, Multifactor Arbitrage Pricing Theory (APT), Return on Equity (ROE), South Africa

* Mr C Ndlovu is a PhD candidate at the Wits Business School, University of the Witwatersrand, Johannesburg, South Africa.

"Prof P Alagidede is professor at the Wits Business School, University of the Witwatersrand, Johannesburg, South Africa. 


\section{INTRODUCTION}

What are the factors that drive the ROE of South Africa's financial companies? To what extent do the aggregate economic conditions and financial information impact on ROE? And how well should companies in the financial services industry hedge against unsystematic and systematic risks? These questions are important for the determination of shareholder value. Arguably, ROE is one of the most important metrics in judging how well a firm performs. Whether a firm is able to generate sufficient profit from every unit of shareholder equity, and whether the firm is efficient in utilising its investment funds to generate earnings growth boils down to ROE. Vintila and Duca (2012) observed that leverage plays a very important role in ROE. High leverage magnifies profits when an asset more than offsets the costs of borrowing and vice versa.

Empirical studies have found that ROE is influenced by three main value drivers, which in turn are influenced by management decisions and economic conditions. Ward and Price (2006) identified these value drivers as profitability, activity and leverage. However, the authors caution that it is far better to look at ROE through the first two value drivers and treat leverage with circumspection, because excessive leverage can result in insolvency and eventually bankruptcy. In another view, Ward and Price (2006) acknowledge that in a profitable business, ROE will be leveraged upward as borrowings increase. Lovemore and Brummer (2003) argue that a firm may increase its ROE by raising more loan capital, but, unless it has the liquidity and earnings before interest and $\operatorname{tax}(\varepsilon B I T)$ to meet its interest obligations, the firm may face liquidation. In Katchova and Enlow's (2013) analysis, the authors suggest that in addition to macro-economic factors, fundamental factors that have an impact on ROE are influenced by decisions around profitability, operating efficiency, and/or financial leverage.

Thus an examination of the relationship between financial leverage and the optimal level of ROE consistent with shareholder value maximisation should form an important consideration for financial firms. Moreover, the interaction between macroeconomic factors and financial information could help us better understand the drivers of ROE. The problem here is that we are not aware of any study that has investigated the extent of financial leverage the financial services firms in South Africa can afford and the optimum level of ROE that is acceptable to shareholders. In addition, it is not clear what the direction of the relationship between ROE and financial leverage in the South African financial services industry is, nor what the optimal response of firms to the changes in financial and macroeconomic variables should be.

This paper explores the extent to which profitability, asset turnover and financial leverage impacts on ROE for South Africa's major financial companies. The paper further examines the direction of the relationship, and accounts for the macroeconomic factors that play a role in determining ROE in South Africa's financial services industry for the period 2002-2012.

The contribution of the paper is threefold: first we focus specifically on South Africa's financial firms. There is substantial literature on the subject in some markets - for example, Ward and Price (2006), Lovemore and Brummer (2003), Firer et al. (2012), Katchova and Enlow (2013), Higgins (2001) and Jordan et al. (2012). However, none is focused on the South African financial services industry. To the best of our knowledge there is no study that specifically addresses these issues in South Africa. Second, we extend the analysis in extant literature by dividing the analysis of the financial sector into its subcategories to better understand both the accounting and economy-wide factors that affect ROE for each subcategory. Third, we examine the implications of the results for gearing, immunisation and good corporate performance. 
The rest of the paper is organised as follows: section 2 presents a review of both the theoretical and empirical literature and points out the existing gaps in our knowledge to which this paper attempts to fill. Section 3 provides a description of the key variables and the research methodology. Sections 4 and 5 present and analyse the empirical results respectively, while section 6 concludes by highlighting the implications of the findings, especially on strategies for optimising ROE.

\section{DETERMINANTS OF ROE: A REVIEW}

This section reviews the literature on the determinants of ROE across various industries and countries and points out the various contributions and the gaps that exist. A significant amount of empirical research on the determinants of ROE employs the DuPont model. In a highly influential study, Herciu, Ogrean and Belascu (2011) looked at the top 20 most profitable companies in the world in 2009 to examine the relationship between net income, return on sales, return on assets (ROA) and ROE. The study found a strong correlation between ROA and ROE, which was expected, given the fact that ROE is influenced by both ROA and the equity multiplier. At the country level, Sheela and Karthikeyan (2012) applied the DuPont model to study the financial performance of the three largest pharmaceutical firms in India between 2003 and 2012. The authors concluded that higher ROE in pharmaceutical firms is achieved by reducing expenses and costs, which subsequently improves profit margins.

Financial leverage is another factor that has been found to have an influence on ROE. Unlike the profit margin and the asset turnover ratio, where more is generally preferred to less, maximising financial leverage is often not the objective of managers of a firm, even if when doing so increases ROE. Instead, the challenge of financial leverage is to strike a prudent balance between the benefits and costs of debt financing. Thus authors such as Higgins (2001) noted that businesses with highly predictable and stable operating cash flows can safely undertake more financial leverage than firms facing a high degree of market uncertainty.

Stambaugh and McGowan (2012) used the DuPont system to perform a financial analysis on Monarch Bank in the United States of America, and their analysis extended from 2003 to 2010. Their analysis demonstrated that the ROA for Monarch Bank was derived primarily from return on loans. The authors noted that institutions in the financial services industry tend to exercise a higher level of financial leverage and consequently exhibit high equity multipliers.

The main weakness of the DuPont model as a fundamental factor model is that it only breaks down profitability (ROE) into three major financial performance ratios, namely profit margin, asset turnover and financial leverage. However, external macro-economic indicators can influence these ratios. Empirical studies have therefore recommended the use of macroeconomic factor models like the multifactor APT model.

Collins (1988) applied the APT model in re-examining the required rates of return for agricultural equity. The author studied the required rates of return for 10 publicly held firms with agricultural operations in the United States of America using quarterly data from 1975 through to 1985. The results suggested that the required rates of return for this group of firms were similar to the required rates of return for an average share of stock.

Hasan, Shaari, Palanimally and Mohamed (2013) examined the impact of macroeconomic and bank-specific components on the ROE of AmBank in Malaysia. They used nine years' quarterly time series data from 2004 to 2012 using the Ordinary Least Squares method. Their findings 
showed that operating efficiency ratio, liquidity ratio, consumer price index (inflation) and financial crisis inversely affect bank profitability (ROE).

Bhutta and Hasan (2013) examined the impact of residual risk and macro-economic factors of the food sector in Pakistan between 2002 and 2006. Their empirical results provided evidence that the profitability of the food sector is shaped by firm-specific factors and not macroeconomic variables. One important limitation of their study was that it considered only one macro-economic factor, food inflation. Contrary to the findings by Bhutta and Hasan (2013), Patro, Wald and Wu (2002) found that several macro-economic variables significantly affected a country's exposure to world market risk. Alper and Anber (2011) examined the determinants of the commercial banks' profitability in Turkey. The authors used bank-specific data from 10 banks and macro-economic factors from 2002 through to 2010. Authors found that only asset size had a positive and significant effect on profitability. The authors also found that when real interest rates are higher, the ROE of banks rises. Ameur and Mhiri (2013) also looked at factors explaining Tunisian banks' performance. Their findings suggest that the bank capitalisation, as well as best managerial efficiency, has a positive and significant effect on banks' performance.

The empirical evidence emerging from the literature around the assumptions and general application of the APT model shows that the model is silent on which macro-economic variables should be considered; accordingly, the selection of macro-economic variables has been arbitrary (Gul and Khan, 2013). Some authors have however recommended that future research initiatives should consider the economic and financial theories underpinning the research interests and choose macro-economic variables based on those two guidelines. In general, authors agree that there is a positive relationship between ROE and the equity multiplier. In particular, Kalluci (2011) found that a decline in ROE could be the result of a decline in two main components of ROE, namely the equity multiplier and ROA. The researchers generally agree that the volatility of $R O E$ is the result of a significant variability in net profit margin and the equity multiplier.

Studies on the impact of macro-economic indicators on firm profitability and stock returns have yielded contradictory conclusions. Authors like Bhutta and Hasan (2013) found no influence from macro-economic indicators, possibly because the authors looked at only one indicator, inflation. On the other hand, authors like Hasan, Shaari, Palanimally and Mohamed (2013) have concluded that macro-economic indicators do affect firm performance.

\section{DATA SOURCES AND DESCRIPTION OF VARIABLES}

The following ratios were extracted from Bloomberg: (i) profit margin, (ii) asset turnover, (iii) financial leverage and (iv) return on equity. There were 629 firm year observations for the 11year period between January 2002 and December 2012. The 629 firm year observations were categorised into six banks with 60 firm year observations, nine insurance companies with 92 firm year observations, 26 real estate companies with 226 firm year observations and 32 investment companies with 251 firm year observations.

GDP figures, interest rates and inflation rates were extracted from Bloomberg, while unemployment rates and exchange rates were extracted from the South African Reserve Bank website. The dependent variable is return on equity. ROE formula is demonstrated below:

Return on equity $=$ profit margin $\times$ asset turnover $\times$ financial leverage. 
We give a brief background to the explanatory variables, their construction and expected relationships below.

a) Profit margin

Net profit margin indicates a company's profitability with regard to its ability to control costs. This ratio was measured as Profit margin $=\frac{\text { Net income }}{\text { Sales }} \times 100 \%$. A positive relationship between profit margin and ROE was expected.

b) Asset turnover

The asset turnover ratio calculates the total revenue earned for every dollar of assets a company owns. This ratio was measured as Asset turnover $=\frac{\text { Sales }}{\text { Total assets }}$. According to Stambaugh and McGowan (2012), an increase in asset turnover will bring about an increase in ROE.

c) Financial leverage (equity multiplier)

The equity multiplier indicates the total assets that the company has available per unit of equity invested by the shareholders. The financial leverage ratio was measured as Financial leverage (equity multiplier) $=\frac{\text { Total assets }}{\text { Equity }}$. With the right amount of debt, financial leverage is expected to have a positive relationship with ROE.

Below are definitions and discussions of the expected relationship between individual macroeconomic indicators and ROE. A positive relationship between GDP and ROE is expected. The repo rate serves as a benchmark for the level of short-term interest rates. To maintain their existing profit margins, banks raise interest rates in response to repo rate increases (SARB, 2012). In light of this domino effect, it is expected that an increase in interest rates will drive interest income upwards, positively influencing the profitability (ROE) of financial firms. Economic theory suggests that an increase in the inflation rate normally depletes revenues, because as inflation increases, spending is reduced and therefore profits and ultimately ROE decrease. In light of this, the relationship between ROE and inflation is expected to be negative, although previous studies have found a positive relationship.

This research defines the exchange rate as the price of domestic currency (South African rand) per unit of foreign currency (United States dollar) where an increase in the rate signifies a depreciation of the local currency and a decrease in the rate signifies an appreciation of the domestic currency. A strengthening currency dampens demand for local goods. Therefore, a negative relationship between exchange rates and ROE is also expected. High unemployment translates into low total disposable income in the economy and therefore less spending. Less spending should mean a negative relationship between unemployment rates and ROE.

\subsection{Research methodology}

Two main models are estimated in this study, the DuPont and the APT. The study employs a panel estimation to examine ROE and its postulated determinants. The DuPont model specifies the relationship between ROE and its financial determinants as follows:

$$
\mathrm{ROE}_{\mathrm{it}}=\beta_{0}+\beta_{1 \mathrm{PM}}\left(\mathrm{PM}_{\mathrm{it}}\right)+\beta_{2 \mathrm{AT}}\left(\mathrm{AT}_{\mathrm{it}}\right)+\beta_{3 \mathrm{FL}}\left(\mathrm{FL}_{\mathrm{it}}\right)
$$


where ROE $E_{i t}$ is the ROE of firm $i$ at time $t$, Profit Margin, Asset Turnover and Financial Leverage are represented by PM, AT and FL respectively. Since the DuPont model uses fundamental factors, which are measured in different metrics, data transformation to induce uniformity was required. Financial theory recommends that explanatory variables of fundamental factor models should be standardised. The profit margin factor was therefore standardised as $\beta_{1 \mathrm{PM}}=\frac{\mathrm{PM}_{\mathrm{t}} \overline{\mathrm{PM}}}{\sigma_{\mathrm{PM}}}$, where $\beta_{1 \mathrm{PM}}$ is the profit margin standardised sensitivity and $\mathrm{PM}_{\mathrm{t}}$ is the profit margin of firm $i$ at time $t . \overline{\mathrm{PM}}$ is the average profit margin per industry category and $\sigma_{\mathrm{PM}}$ is the standard deviation of profit margin per industry category. All other independent variables included in the specification were transformed in a similar fashion.

Researchers have found that institutions with higher equity will usually report higher ROA but, expectedly, lower ROE, suggesting that there is positive relationship between ROE and financial leverage.

Our second model is the APT. The APT model allows for the analysis of factors that affect ROE by examining both fundamental and macro-economic factors. The APT model thus nests both the accounting variables with the macro-economic variables. The specific form of the APT applied in this research is as follows:

$$
\begin{gathered}
R O E_{i t}=\beta_{0}+\beta_{1}\left(P M_{i t}\right)+\beta_{2}\left(A T_{i t}\right)+\beta_{3}\left(F L_{i t}\right)+\beta_{4}\left(U_{i t}\right)+\beta_{5}\left(E_{i t}\right)+\beta_{6}\left(G D P_{i t}\right) \\
+\beta_{7}\left(I_{i t}\right)+\beta_{8}\left(I n f_{i t}\right)
\end{gathered}
$$

where $\mathrm{ROE}_{\mathrm{it}}$ is the return on equity of firm $i$ at time $t, \mathrm{U}, \mathrm{E}, \mathrm{GDP}$, Int and Inf captures the key explanatory variables of Unemployment Rate, Exchange Rate, GDP Growth rate, Interest rates (Repo) and Inflation Rate respectively.

We are well aware of the problems involved in estimating equations 1 and 2 in a panel setting. To overcome the time and cross-sectional dependence inherent in our data and model, we estimate a pooled regression in which both equations 1 and 2 are estimated using single equation on all the data set together, so that our dependent variable, ROE is stacked up into a single column containing all the cross-sectional and time series observations, and similarly all of the observations on each explanatory variable are stacked up in a single column. This makes it possible for us to then employ OLS in the usual fashion.

The choice of the model was supported by the assumptions of the APT model, which postulates that stock returns can be explained by reference to the unexpected changes in the macroeconomic variables rather than their levels. To capture the effects of unexpected changes of variables, aligning with the assumptions of the APT model, ROE required first differencing. In addition, in order to induce stationarity and to avoid spurious regressions, all the variables were subjected to unit root tests (results available upon request). The inclusion of the lag of ROE is supported by econometric theory. According to Brooks (2008:155), allowing for lagged effects is likely to reduce, and possibly remove, serial correlation.

\section{EMPIRICAL RESULTS}

Descriptive statistics for fundamental and macro-economic factors are presented first; these are followed by a trend analysis, then a correlation matrix and an analysis of the regression results. The DuPont model results and the APT model results are given. 


\subsection{Preliminary analysis}

\subsubsection{Descriptive statistics}

TABLE 1 presents descriptive statistics for the accounting variables and macroeconomic indicators.

\section{TABLE 1: Descriptive statistics}

\begin{tabular}{|c|c|c|c|c|c|c|c|c|c|}
\hline Statistic & 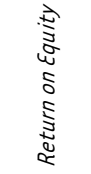 & $\begin{array}{c}5 \\
5 \\
5 \\
5 \\
5 \\
\vdots \\
0 \\
0 \\
2\end{array}$ & 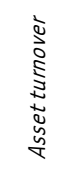 & 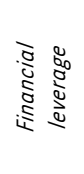 & 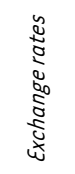 & $\begin{array}{l}0 \\
0 \\
0 \\
0 \\
0 \\
0 \\
0 \\
0 \\
0 \\
5 \\
5\end{array}$ & 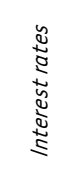 & هิ & $\begin{array}{l}\frac{N}{5} \\
\text { है } \\
0 \\
\frac{d}{2} \\
\frac{2}{0} \\
\frac{5}{2} \\
\frac{5}{5}\end{array}$ \\
\hline Minimum & -2006.7 & -569.17 & 0 & -64.34 & 6.36 & 1.4 & 5.41 & -1.56 & 22.3 \\
\hline Maximum & 792.1 & 465.98 & 3.15 & 572.83 & 10.52 & 11 & 11.85 & 8.61 & 28.85 \\
\hline Median & 17.4 & 19.76 & 0.15 & 2.47 & 7.32 & 5.7 & 7.92 & 4.88 & 24.7 \\
\hline Mean & 14.22 & 33.97 & 0.31 & 6.68 & 7.63 & 5.9 & 8.34 & 4.7 & 24.56 \\
\hline $\begin{array}{l}\text { Standard } \\
\text { Deviation }\end{array}$ & 94.82 & 81.38 & 0.36 & 24.34 & 1.06 & 2.5 & 2.25 & 2.55 & 1.79 \\
\hline Skewness & -14.55 & -0.29 & 2.72 & 20.22 & 1.26 & 0.39 & 0.32 & -0.94 & 0.92 \\
\hline Kurtosis & 337.37 & 13.02 & 13.47 & 467.83 & 4.51 & 2.85 & 1.8 & 4.17 & 3.39 \\
\hline Observation & 629 & 629 & 629 & 629 & 629 & 629 & 629 & 629 & 629 \\
\hline
\end{tabular}

Source: Authors' calculations

Profit margins and financial leverage for South African financial firms appeared to have wide deviations from the mean based on the standard deviation measure. In contrast, asset turnover did not deviate widely from the mean. Asset turnover and financial leverage were positively skewed, which indicates that asset turnover and financial leverage values for the majority of South African financial firms were higher than the mean. Profit margin and ROE values were negatively skewed, which indicates that profit margin and ROE values for the majority of South African financial firms were lower than the mean.

Positively skewed results were observed for all variables except GDP growth rates. Interesting to note was the negative growth of -1.56 and a negatively skewed result of -0.94 for GDP. This could possibly point to the sluggish economic growth between 2007 and 2009 when the financial crisis was eventually felt in most parts of the world.

\subsubsection{Correlation matrix}

We also produce the correlation matrix for the variables in TABLE 2 to measure the degree of association between them.

A positive correlation between ROE and an explanatory variable would mean that the two move together, while a negative correlation between $\mathrm{ROE}$ and an explanatory variable would imply the opposite.

The correlation matrix shows that ROE has a positive correlation with profit margin and asset turnover. In contrast, there appears to be a negative correlation between ROE and financial leverage. 
TABLE 2: Correlation matrix

\begin{tabular}{|c|c|c|c|c|c|c|c|c|c|}
\hline Variable & 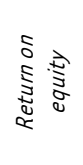 & $\begin{array}{l}5 \\
50 \\
5 \\
5 \\
\vdots \\
0 \\
0 \\
2\end{array}$ & 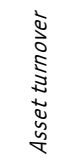 & 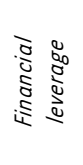 & S & 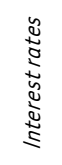 & $\begin{array}{l}0 \\
0 \\
0 \\
0 \\
\vdots \\
\vdots \\
0 \\
\vdots \\
\vdots\end{array}$ & 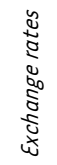 & 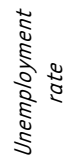 \\
\hline Return on Equity & 1.00 & & & & & & & & \\
\hline Profit Margin & 0.21 & 1.00 & & & & & & & \\
\hline Asset Turnover & 0.04 & -0.16 & 1.00 & & & & & & \\
\hline Financial Leverage & -0.11 & 0.07 & -0.08 & 1.00 & & & & & \\
\hline GDP Growth Rates & 0.09 & 0.18 & 0.10 & -0.01 & 1.00 & & & & \\
\hline Interest Rates & -0.02 & -0.14 & 0.03 & 0.03 & -0.10 & 1.00 & & & \\
\hline Inflation Rates & -0.04 & -0.18 & -0.07 & 0.05 & -0.44 & 0.65 & 1.00 & & \\
\hline Exchange Rates & -0.07 & -0.20 & -0.04 & 0.00 & -0.49 & 0.47 & 0.72 & 1.00 & \\
\hline Unemployment Rates & -0.04 & -0.10 & 0.07 & -0.05 & -0.08 & 0.24 & -0.07 & 0.38 & 1.00 \\
\hline
\end{tabular}

Source: Authors' calculations

ROE had negative correlations with all macro-economic indicators except for GDP growth rates. The observation made theoretical and economic sense, because increased interest rates, for example, increase debt obligations, which in turn decreases profit margins and ultimately negatively affects ROE. However, as GDP growth rates increases, companies were likely to increase sales and therefore increase profit margins that positively affect ROE.

\subsection{Regression analysis}

Regression analysis is the main methodology of the study. Deeper understanding of the relationship between the independent variables and ROE is achieved by way of a scientific and robust form of analysis, and the significance of the model statistics is discussed at length.

The DuPont model and multifactor APT model analyses are presented next.

\subsubsection{DuPont model analysis}

In a quest for a deeper understanding of the relationship between ROE and fundamental factors, the DuPont model relationship was technically examined. TABLE 3 presents the empirical findings from the DuPont model, where ROE was regressed against profit margin, asset turnover and financial leverage. 
TABLE 3: DuPont model results

\begin{tabular}{|c|c|c|c|c|c|}
\hline \multicolumn{3}{|l|}{ Dependent Variable : DROE } & \multicolumn{3}{|l|}{ Categories } \\
\hline Variable & Industry & Banks & $\begin{array}{l}\text { Insurance } \\
\text { Companies }\end{array}$ & $\begin{array}{l}\text { Real Estate } \\
\text { Companies }\end{array}$ & $\begin{array}{l}\text { Investment } \\
\text { Companies }\end{array}$ \\
\hline C & $\begin{array}{l}-12.311^{\star \star \star *} \\
(-3.562)\end{array}$ & $\begin{array}{l}-10.860 \\
(-1.314)\end{array}$ & $\begin{array}{l}-6.036 \\
(-1.416)\end{array}$ & $\begin{array}{c}-9.927 \star * \\
(-3.562)\end{array}$ & $\begin{array}{l}-7.859 \\
(-0.892)\end{array}$ \\
\hline ROE-1 & $\begin{array}{l}0.929 * \star * \\
(21.340)\end{array}$ & $\begin{array}{c}0.353 \\
(1.348)\end{array}$ & $\begin{array}{l}0.386^{*} \\
(1.980)\end{array}$ & $\begin{array}{c}0.805^{* * *} \\
(5.050)\end{array}$ & $\begin{array}{l}0.945^{* * *} \\
(19.351)\end{array}$ \\
\hline PM_STD_SENSITIVITY & $\begin{array}{l}-5.112^{\star \star} \\
(-2.069)\end{array}$ & $\begin{array}{c}1.491 \\
(0.378)\end{array}$ & $\begin{array}{l}5.324 \star \star \\
(2.293)\end{array}$ & $\begin{array}{l}-2.618 \\
(-0.716)\end{array}$ & $\begin{array}{c}-8.011 \\
(-1.484)\end{array}$ \\
\hline AT_STD_SENSITIVITY & $\begin{array}{l}-0.301 \\
(-0.141)\end{array}$ & $\begin{array}{c}4.745 \\
(1.356)\end{array}$ & $\begin{array}{c}3.397 \\
(1.175)\end{array}$ & $\begin{array}{c}0.984 \\
(0.275)\end{array}$ & $\begin{array}{l}-2.476 \\
(-0.611)\end{array}$ \\
\hline FL_STD_SENSITIVITY & $\begin{array}{c}0.591 \\
(0.219)\end{array}$ & $\begin{array}{c}2.116 \\
(0.477)\end{array}$ & $\begin{array}{c}2.892 \\
(1.540)\end{array}$ & $\begin{array}{l}-8.225 \\
(-1.189)\end{array}$ & $\begin{array}{c}7.414 \\
(1.136)\end{array}$ \\
\hline Adjusted R-squared & 0.455 & 0.102 & 0.333 & 0.414 & 0.46 \\
\hline Akaike info criterion & 11.947 & 8.358 & 8.622 & 10.543 & 12.78 \\
\hline Schwarz criterion & 11.983 & 8.534 & 8.759 & 10.618 & 12.850 \\
\hline F-statistic & $\begin{array}{l}132.259 * \pi * \\
{[0.000]}\end{array}$ & $\begin{array}{l}2.659 * \star \\
{[0.042]}\end{array}$ & $\begin{array}{l}12.371^{\star \star \star *} \\
{[0.000]}\end{array}$ & $\begin{array}{l}40.884^{\star \star \star} \\
{[0.000]}\end{array}$ & $\begin{array}{c}54.317^{\star \star \star} \\
{[0.000]}\end{array}$ \\
\hline $\begin{array}{l}\text { Breusch-Godfrey Serial Correlation } \\
\text { LM Test(5) }\end{array}$ & $\begin{array}{c}0.429 \\
{[0.994]}\end{array}$ & $\begin{array}{c}1.727 \\
{[0.885]}\end{array}$ & $\begin{array}{c}3.945 \\
{[0.557]}\end{array}$ & $\begin{array}{c}6.820 \\
{[0.234]}\end{array}$ & $\begin{array}{c}0.122 \\
{[0.999]}\end{array}$ \\
\hline Durbin-Watson stat & 2.004 & 1.612 & 2.256 & 1.775 & 2.08 \\
\hline $\begin{array}{l}\text { Heteroskedasticity Test: Breusch- } \\
\text { Pagan-Godfrey }\end{array}$ & $\begin{array}{c}1.115 \\
{[0.891]}\end{array}$ & $\begin{array}{c}3.519 \\
{[0.474]}\end{array}$ & $\begin{array}{c}12.882 \\
{[0.011]}\end{array}$ & $\begin{array}{c}2.782 \\
{[0.594]}\end{array}$ & $\begin{array}{c}0.729 \\
{[0.947]}\end{array}$ \\
\hline
\end{tabular}

Source: Authors' calculations

$\star, \star \star, \star \star \star$ indicate significance at $10 \%, 5 \%$ and $1 \%$ levels, respectively. Values in () and [ ] indicates $t$-statistics and $p$-values respectively. LM Test (5) is the Lagrange Multiplier test up to 5 lags. PM_STD_SENSITIVITY, AT_STD_SENSITIVITY, FL_STD_SENSITIVITY, DROE, and ROE-1 refer to profit margin standardised sensitivity, asset turnover standardised sensitivity, financial leverage standardised sensitivity, first difference of return on equity, and lag of return on equity respectively. 73 South African financial companies listed on the JSE, 2002 to 2012: 629 firm year observations

Although some coefficients were insignificant, the joint significance test indicated by the Fstatistic shows that all the variables in the DuPont model have some significance, albeit weak. The DuPont model results, on average, show that $33 \%$ of the variation in ROE in the South African financial services industry was explained by the variation in profit margin, asset turnover and financial leverage. Thus for the entire industry, the DuPont model has very weak explanatory powers in respect of the chosen variables. An analysis of the results, sector by sector, could throw more light on the estimations.

\section{a) Relationship between profit margin and ROE}

In banking, empirical evidence showed that there is a positive relationship between profit margin and ROE although the relationship was insignificant. In contrast, the coefficient of profit margin for insurance companies was positive and significant at the $5 \%$ level. All else being equal, the results showed that a $1 \%$ increase in profit margin resulted in a $5.32 \%$ increase in ROE.

Generally, the South African financial services industry profit margin explained the variations in ROE to a significant degree. Results show a negative profit margin coefficient, which is significant at the $5 \%$ level. This contradicts findings by researchers such as Almazari (2012), 
Stambaugh and McGowan (2012), Georgios and Georgios (2011) and Sharma and Gounder (2011), who generally agree that the ROE volatility results from a significant variability in net profit margin.

\section{b) Relationship between asset turnover and ROE}

Banks, insurance companies and real estate companies all showed a positive but insignificant relationship between asset turnover and ROE. Real estate companies have the weakest relationship. In contrast, investment companies show a negative and insignificant relationship between asset turnover and ROE.

\section{c) Relationship between financial leverage and ROE}

Banks, insurance companies and investment companies all show a positive but insignificant relationship between financial leverage and ROE. Overall, there is a positive but insignificant relationship between financial leverage and ROE in the South African financial services industry. These results are in conflict with Vintila and Duca's (2012) empirical findings, where a significant positive impact between high debt levels and ROE was found. One would infer that although the theory of financial leverage holds, performance in the South African financial services industry is not that dependent on leverage.

Having examined the results from the DuPont model in light of its limitations, we now turn to the multifactor APT model results, which include macro-economic variables. These results are expected to illuminate our understanding of the drivers of ROE in the South African financial services industry.

\subsubsection{Multifactor APT model analysis}

TABLE 4 presents the empirical findings from the multifactor APT model, where ROE was regressed against profit margin, asset turnover, financial leverage, GDP, interest rates, inflation rates, exchange rates and unemployment rates.

The adjusted R-squared is a more robust method of measuring the percentage variation in the dependent variable that is explained by the variation in the independent variables. On average, $47 \%$ of the variation in ROE was explained by the variation in all explanatory variables. This is $14 \%$ higher than the explanatory power presented by the DuPont model. The observed relationship between each independent variable and ROE is explored in detail.

\section{a) Relationship between profit margin and ROE}

Multifactor APT model results show that the coefficient of profit margin across all categories was positive and significant at the $1 \%$ level, except for investment companies, where the coefficient was also positive but only significant at the $10 \%$ level. These results suggest that managers in the financial services industry need to focus on areas that could help to increase profit margins, because in so doing they will be able to improve their ROE. 
Ndlovu \& Alagidede

TABLE 4: Multifactor APT model results

\begin{tabular}{|c|c|c|c|c|c|}
\hline $\begin{array}{c}\text { Dependent Variable: } \\
\text { DROE }\end{array}$ & & & ategories & & \\
\hline Variable & Industry & Banks & $\begin{array}{l}\text { Insurance } \\
\text { Companies }\end{array}$ & $\begin{array}{l}\text { Real Estate } \\
\text { Companies }\end{array}$ & $\begin{array}{l}\text { Investment } \\
\text { Companies }\end{array}$ \\
\hline C & $\begin{array}{c}-11.948 * \star \star \\
(-3.334)\end{array}$ & $\begin{array}{l}-8.100 \\
(-1.381)\end{array}$ & $\begin{array}{l}-6.239 \star \star \\
(-2.424)\end{array}$ & $\begin{array}{l}-7.487 \star \star \\
(-2.381)\end{array}$ & $\begin{array}{l}-7.684 \\
(-0.864)\end{array}$ \\
\hline ROE-1 & $\begin{array}{l}0.900 \star \star \star \\
(26.726)\end{array}$ & $\begin{array}{l}0.296 * \\
(1.879)\end{array}$ & $\begin{array}{c}0.349 \star \star \star \\
(3.308)\end{array}$ & $\begin{array}{c}0.498 * \star \star \\
(2.771)\end{array}$ & $\begin{array}{l}0.916 * \star \star \\
(25.776)\end{array}$ \\
\hline DPM & $\begin{array}{l}0.183 \star \star \star \\
(3.022)\end{array}$ & $\begin{array}{c}0.263 * \star \star \\
(3.859)\end{array}$ & $\begin{array}{c}0.319 \star \star \star \\
(3.742)\end{array}$ & $\begin{array}{c}0.150 * \star \star \\
(4.274)\end{array}$ & $\begin{array}{l}0.263 \star \\
(1.885)\end{array}$ \\
\hline DAT & $\begin{array}{l}15.331 \\
(1.477)\end{array}$ & $\begin{array}{c}48.043 \star \star \star \\
(5.118)\end{array}$ & $\begin{array}{c}53.073 \star \star \star \\
(5.369)\end{array}$ & $\begin{array}{l}-27.868 \\
(-1.533)\end{array}$ & $\begin{array}{l}18.782 \\
(1.228)\end{array}$ \\
\hline DFL & $\begin{array}{l}-0.249 \\
(-0.746)\end{array}$ & $\begin{array}{l}2.292 * \star \star \\
(2.914)\end{array}$ & $\begin{array}{l}0.988 * \star \\
(2.095)\end{array}$ & $\begin{array}{c}-4.804 \star \star \star \\
(-3.472)\end{array}$ & $\begin{array}{l}-0.229 \\
(-0.626)\end{array}$ \\
\hline DGDP & $\begin{array}{c}0.530 \\
(0.819)\end{array}$ & $\begin{array}{l}1.614 * \star \star \\
(2.911)\end{array}$ & $\begin{array}{c}0.543 \\
(1.162)\end{array}$ & $\begin{array}{c}-0.765 \\
(-1.016)\end{array}$ & $\begin{array}{c}0.789 \\
(0.551)\end{array}$ \\
\hline DINT & $\begin{array}{l}(-1.366) \\
(-0.594)\end{array}$ & $\begin{array}{c}1.136 \\
(0.795)\end{array}$ & $\begin{array}{c}0.675 \\
(0.588)\end{array}$ & $\begin{array}{c}0.123 \\
(0.055)\end{array}$ & $\begin{array}{l}-5.946 \\
(-1.145)\end{array}$ \\
\hline DINF & $\begin{array}{c}0.895 \\
(0.329)\end{array}$ & $\begin{array}{c}-0.712 \\
(-0.484)\end{array}$ & $\begin{array}{l}-1.253 \\
(-1.310)\end{array}$ & $\begin{array}{l}-0.699 \\
(-0.495)\end{array}$ & $\begin{array}{c}5.358 \\
(0.878)\end{array}$ \\
\hline DE & $\begin{array}{l}-1.874 \\
(-0.653)\end{array}$ & $\begin{array}{c}2.764 \\
(1.220)\end{array}$ & $\begin{array}{l}-0.767 \\
(-0.516)\end{array}$ & $\begin{array}{l}-7.549 \star \\
(-1.754)\end{array}$ & $\begin{array}{l}-5.399 \\
(-1.377)\end{array}$ \\
\hline DU & $\begin{array}{l}2.791 * \star \\
(2.040)\end{array}$ & $\begin{array}{l}-1.009 \\
(-0.585)\end{array}$ & $\begin{array}{l}-0.434 \\
(-0.520)\end{array}$ & $\begin{array}{c}0.143 \\
(0.071)\end{array}$ & $\begin{array}{l}5.271^{\star} \\
(1.853)\end{array}$ \\
\hline Adjusted R-squared & 0.469 & 0.503 & 0.725 & 0.669 & 0.466 \\
\hline Akaike info criterion & 11.929 & 7.839 & 7.785 & 9.993 & 12.787 \\
\hline Schwarz criterion & 11.999 & 8.191 & 8.059 & 10.144 & 12.927 \\
\hline F-statistic & $\begin{array}{c}62.771 * \star \star \\
{[0.000]}\end{array}$ & $\begin{array}{l}7.528 * \star \star \\
{[0.000]}\end{array}$ & $\begin{array}{c}27.698 * \star \star \\
{[0.000]}\end{array}$ & $\begin{array}{c}51.636 \star \star \star \\
{[0.000]}\end{array}$ & $\begin{array}{c}25.338 * \star \star \\
{[0.000]}\end{array}$ \\
\hline $\begin{array}{l}\text { Breusch-Godfrey Serial } \\
\text { Correlation LM Test( } 5 \text { ) }\end{array}$ & 0.948 & 0.794 & 0.164 & 0.139 & 0.992 \\
\hline Durbin-Watson stat & 2.030 & 1.944 & 2.098 & 1.928 & 2.064 \\
\hline $\begin{array}{l}\text { Heteroskedasticity Test: } \\
\text { Breusch-Pagan-Godfrey }\end{array}$ & 0.220 & 0.188 & 0.332 & 0.008 & 0.607 \\
\hline
\end{tabular}

Source: Authors' calculations

$\star * * *, * *$ indicate significance at $10 \%, 5 \%$ and $1 \%$ levels, respectively. Values in () and [ ] indicates $t$-statistics and $p$-values respectively. $L M$ Test (5) is the Lagrange Multiplier test up to 5 lags. DPM, DAT, DFL, DGDP, DINT, DINF, DE, DU, DROE, and ROE-1 refer to the first differences of the profit margin, asset turnover, financial leverage, gross domestic product, interest rates, inflation, exchange rates, the unemployment rate return on equity respectively. ROE-1 is defined as in TABLE 3.73 South African financial companies listed on the JSE, 2002 to 2012: 629 firm year observations. 


\section{b) Relationship between asset turnover and ROE}

There was a positive relationship between asset turnover and ROE for banks, insurance companies and investment companies, although the relationship for investment companies is not significant, banks' asset turnover coefficient is positive and significant at the $1 \%$ level. In contrast to all other categories, real estate companies had a negative asset turnover coefficient, which was not significant.

\section{c) Relationship between financial leverage and ROE}

The results for financial leverage show that the coefficient for banks was positive and significant at the $1 \%$ level. Insurance companies showed a coefficient that was positive and significant at the $10 \%$ level. In contrast, financial leverage results for real estate companies showed a negative coefficient that was significant at the $1 \%$ level. The results suggest that if bank and insurance company managers establish an optimal capital structure driven by a moderate dose of debt and efficient capital utilisation, ROE will improve positively. The negative relationship between financial leverage for real estate companies and ROE suggested that real estate managers need to use debt with circumspection. At an industry level, the negative financial leverage coefficient is consistent with a study that was conducted by Fathi, Zarei and Esfahani (2012), who found that interest rate risk as a result of financial leverage in banks leads to a reduction in banks' net income (profitability), which generally would have a negative effect on ROE.

\section{d) Relationship between GDP and ROE}

This study found that GDP had a significant positive impact on banks' profitability. The relationship is found to be significant at the $1 \%$ level. The results suggest that bank managers can be aggressive during the expansionary phases of the business cycle when GDP improves, since an increase in GDP has been scientifically proven to have a positive impact on ROE.

\section{e) Relationship between interest rates and ROE}

The empirical results show a negative relationship for the South Africa's financial services industry which includes investment companies, a positive relationship for banks, insurance companies and real estate companies. Although not significant, the results for banks, insurance companies and real estate companies suggested that if these companies price their products efficiently as interest rates increase, the chances are that they can improve their ROE in the process. The results for the industry and investment companies were in conflict with Alper and Anbar's (2011) empirical findings: they found that profitability was positively associated with interest rates. In contrast, the results were consistent with Bhutta and Hasan (2013), who found no relationship between profitability and macro-economic variables.

\section{f) Relationship between inflation rates and ROE}

In general, an increase in inflation reduces buying power, eventually impacting profits and ROE. The observed negative relationship between inflation rates and ROE could possibly suggest that financial managers should be proactive in cost containment. On the other hand, investment companies experienced a positive relationship, although insignificant, between inflation rates and ROE. These results were shared with Alper and Anbar (2011), who found that GDP and inflation were not associated with profitability. 


\section{g) Relationship between exchange rates and ROE}

The exchange rates coefficient for real estate companies was negative and significant at the $10 \%$ level, which means that an appreciation of the local currency resulted in a drop in ROE. These results were consistent with the works of Ali, Zakaria and Husni (cited in Bilal, Saeed, Gull \& Akram, 2013), who concluded that ROE had an unfavourable relationship with exchange rates.

\section{h) Relationship between unemployment rates and ROE}

The unemployment rates coefficient for investment companies is significant and positive at the $10 \%$ level, which means that if all else is constant, a $1 \%$ increase in the unemployment rates resulted in a $5.27 \%$ increase in ROE. Overall, industry coefficients were positive and significant at the $5 \%$ level. This is confirmation that unemployment rates explained the variability in ROE to a significant degree. All else being constant, the results indicate that a $1 \%$ increase in unemployment rates resulted in a $2.79 \%$ increase in ROE.

The empirical results showed that the APT model explains the variability in ROE of South African financial firms better. The DuPont model did explain the variability in ROE, albeit marginally, with the exception of banks' profit margin. Almost all of the fundamental factors explained the variability of ROE to a significant degree. On the macro-economic factors, GDP, exchange rates and unemployment were found to have some degree of explanatory power in relation to the variability of ROE for banks, real estate companies and investment companies respectively. Statistically, interest rates and inflation were found to have minimal influence on the changes in ROE across all categories.

\section{DISCUSSION OF RESULTS}

TABLE 5 contains a summary of the significance and effectiveness of each model and a comparison thereof.

\section{TABLE 5: DuPont model versus APT model}

\begin{tabular}{|c|c|c|c|c|c|c|c|}
\hline Model & Statistic & Industry & Banks & $\begin{array}{l}\text { Insurance } \\
\text { Companies }\end{array}$ & $\begin{array}{l}\text { Real Estate } \\
\text { Companies }\end{array}$ & $\begin{array}{l}\text { Investment } \\
\text { Companies }\end{array}$ & Average \\
\hline APT & AIC & 11.929 & 7.839 & 7.785 & 9.993 & 12.787 & 9.601 \\
\hline Du Pont & AIC & 11.947 & 8.358 & 8.622 & 10.543 & 12.78 & 10.076 \\
\hline APT & SBIC & 11.999 & 8.191 & 8.059 & 10.144 & 12.927 & 9.830 \\
\hline Du Pont & SBIC & 11.983 & 8.534 & 8.759 & 10.618 & 12.85 & 10.190 \\
\hline APT & $\bar{R}^{2}$ & 0.469 & 0.503 & 0.725 & 0.669 & 0.466 & 0.591 \\
\hline Du Pont & $\bar{R}^{2}$ & 0.455 & 0.102 & 0.333 & 0.414 & 0.460 & 0.327 \\
\hline APT & F-stat & $\star \star \star$ & $\star \star \star$ & $\star \star \star$ & $\star \star \star$ & $\star \star \star$ & $\checkmark$ \\
\hline Du Pont & F-stat & $\star \star \star$ & $\star \star$ & $\star \star \star$ & $\star \star \star$ & $\star \star \star$ & $x$ \\
\hline APT & DW & 2.030 & 1.944 & 2.098 & 1.928 & 2.064 & 2.009 \\
\hline Du Pont & DW & 2.004 & 1.612 & 2.256 & 1.775 & 2.080 & 1.931 \\
\hline
\end{tabular}

Source: Authors' calculations 
AIC, SBIC, $\bar{R} 2, F$-stat, and DW refer to Akaike's information criterion, Schwarz's Bayesian information criterion, R-squared, Fstatistic, and Durbin-Watson statistic respectively.

It is important to note that the APT model shows superior results across all model selection statistics and diagnosis: for example, the adjusted R-squared for the APT model shows that the model managed to explain close to $60 \%$ of the variation in the ROE that is explained by the explanatory variables. This is $27 \%$ higher than what is explained by the DuPont model. TABLE 6 provides a summary of key findings from the APT model.

\section{TABLE 6: Observed relationship between independent variables and ROE - APT}

\begin{tabular}{|c|c|c|c|c|c|}
\hline \multicolumn{6}{|c|}{ Observed relationship between Independent Variables and Return on Equity } \\
\hline Independent Variable & Industry & Banks & $\begin{array}{l}\text { Insurance } \\
\text { Companies }\end{array}$ & $\begin{array}{l}\text { Real Estate } \\
\text { Companies }\end{array}$ & $\begin{array}{l}\text { Investment } \\
\text { Companies }\end{array}$ \\
\hline Profit Margin & $+\star \star \star$ & $+\star \star \star$ & $+\star \star \star$ & $+\star \star \star$ & $+*$ \\
\hline Asset Turnover & + & $+\star \star \star$ & $+\star \star \star$ & - & + \\
\hline Financial Leverage & - & $+\star \star \star$ & $+\star \star \star$ & $-\star \star \star$ & - \\
\hline Gross Domestic Product & + & $+\star \star \star$ & + & - & + \\
\hline Interest Rates & - & + & + & + & - \\
\hline Inflation Rates & + & - & - & - & + \\
\hline Exchange Rates & - & + & - & $-\star$ & - \\
\hline Unemployment Rates & $+\star \star$ & - & - & + & $+*$ \\
\hline
\end{tabular}

Source: Authors' calculations

+ means that an increase/decrease in the independent variable results in an increase/decrease in the dependent variable. means that an increase/decrease in the independent variable results in a decrease/increase in the dependent variable. $*, * *, * * *$ indicates model significance at $10 \%, 5 \%$ and $1 \%$ levels, respectively.

In line with the findings of researchers such as Stambaugh and McGowan (2012), Georgios and Georgios (2011) and Sharma and Gounder (2011), this study finds a significant and positive relationship between profit margin and ROE. This suggests that managers in the financial services industry can achieve the desired levels of ROE if they focus their efforts on strategies like cost leadership, which amplify profit margin.

Asset turnover was found to have a significant positive relationship with ROE for banks and insurance companies. The results are consistent with the findings by Higgins (2001), who discovered that financial performance improves as asset turnover rises. This suggests that management in the financial services industry may well improve ROE if their sales and marketing strategies remain relevant to customer needs as well as drive cross-selling.

Empirical evidence of a positive and significant relationship between financial leverage and ROE for banks and insurance companies was found. These findings are in line with work done by Vintila and Duca (2012), who concluded that high debt levels have a significant positive impact on ROE. This suggests that banks and insurance companies can lever ROE upwards by using high levels of debt backed up by predictable cash flows, whereas real estate and investment companies need to treat debt usage with circumspection. 
The empirical results provide evidence of a positive and highly significant relationship between GDP and ROE for banks. These findings are in line with the works of Salehi and Derakhshan (2012), which may suggest that bank managers can improve their ROE during good economic times by employing aggressive revenue-generating strategies. Alper and Anber (2011) found that real GDP growth rate and inflation rate did not have an important effect on profitability.

This study has found that an insignificant relationship exists between GDP and ROE for the other categories of the South African financial sector. Although statistically insignificant, the positive relationship between interest rates and ROE suggests that managers in the financial sector should make decisions that are observant of this behaviour - for example, managers can employ short-term duration gap strategies that will help manage any mismatch between assets and liabilities. The negative relationship between inflation rates and ROE, although insignificant, suggests that managers should perhaps consider counter-inflationary strategies like hedging or taking insurance protection against inflation-sensitive portfolios.

Exchange rates appear to have a minimal effect on ROE. Only real estate companies experience exchange rates to be significant and negatively related to ROE. Perhaps real estate managers need to employ hold strategies when local currency strengthens.

This study finds no significant relationship between unemployment and ROE for banks, insurance and real estate companies, although the overall industry view shows a positive and significant relationship. A positive relationship between unemployment and ROE could possibly suggest that companies tend to make more profits during periods of high unemployment because of a lesser burden in staff costs in their income statements.

\section{CONCLUSION}

This paper analysed the factors that determine ROE in a cross-section of financial firms listed on the Johannesburg Securities Exchange between 2002 and 2012. Two main methods were employed: a DuPont model that allowed us to decompose ROE into its constituent parts and a multifactor arbitrage model that enabled us to examine the impact of macro-economic factors on return on equity. We found a positive relationship between profit margin and ROE, and this can be enhanced if managers employ cost leadership strategies that amplify profits and therefore ROE. A positive relationship between asset turnover and ROE in our results also suggests that by employing aggressive sales and marketing strategies, consumer loyalty and brand identity can be improved.

We established that financial firms with predictable cash flows like banks and insurance companies can afford high levels of debt and therefore high ROE. On the other hand, companies like real estate and investment companies, which are more directly affected by unpredictable market conditions, should use debt with caution. Additionally, aggressive growth strategies, such as being less conservative in credit extension can result in higher ROE when the economic outlook is positive, and aggressive soliciting of deposits during an economic downturn can help fund extension of credit, thereby moderating ROE. Macroeconomic variables such as exchange rates, inflation and the unemployment rate tend to affect return on equity. 


\section{LIST OF REFERENCES}

Almazari, A.A. (2012). Financial Performance Analysis of the Jordanian Arab Bank by Using the DuPont System of Financial Analysis. International Journal of Economics and Finance, 4(4), pp. 86-94.

Alper, D. and Anbar, A. (2011). Bank Specific and Macroeconomic Determinants of Commercial Bank Profitability: Empirical Evidence from Turkey. Business and Economics Research Journal, 2(2), pp. 139-152.

Ameur, I.G.B. \& Mhiri, S.M. (2013). Explanatory Factors of Bank Performance: Evidence from Tunisia. International Journal of Economics, Finance and Management, 2(1), pp. 143-152.

Bhutta, N.T. \& Hasan, A. (2013). Impact of Firm Specific Factors on Profitability of Firms in Food Sector. Open Journal of Accounting, 2, pp. 19-25.

Bilal, M., Saeed, A., Gull, A.A. \& Akram, T. (2013). Influence of Bank Specific and Macroeconomic Factors on Profitability of Commercial Banks: A Case Study of Pakistan. Research Journal of Finance and Accounting, 4(2), pp. 117-126.

Brooks, C. (2008). Introductory Econometrics for Finance, $2^{\text {nd }}$ edition. New York: Cambridge University Express.

Collins, R.A. (1988). The required rate of return for publicly help Agricultural equity: An Arbitrage Pricing Theory Approach. Western Journal of Agricultural economics, 13(2), pp. 163-168.

Fathi, S., Zarei, F. \& Esfahani, S. S. (2012). Studying the Role of Financial Risk Management on Return on Equity. International Journal of Business and Management, 7(9), pp. 215-221.

Firer, C., Ross, S.A., Westerfield, R.W. \& Jordan, B.D. (2012). Fundamentals of Corporate Finance, $5^{\text {th }}$ edition. Berkshire: McGraw-Hill.

Georgios, K. \& Georgios, H. (2011). DuPont Analysis of a Bank Merger and Acquisition between Laiki Bank from Cyprus and Marfin Investment Group from Greece: Is there an increase of profitability of the new bank?. MIBES Transactions, 5(2), pp. 30-49.

Gul, A. \& Khan, N. (2013). An application of Arbitrage Pricing Theory on KSE-100 Index: A study from Pakistan (2000-2005). Journal of Business and Management, 7(6), pp. 78-84.

Hasan, N.A., Shaari, N.A., Palanimally, Y.R. \& Mohamed, R.K.M.H. (2013). The impact of macroeconomic and bank specific components on the return on equity. Interdisciplinary journal of contemporary research in business, 5(2), pp. 106-125.

Herciu, M., Ogrean, C. \& Belascu, L. (2011). A DuPont Analysis of the 20 Most Profitable Companies in the World. Group, 13(1.58), pp. 18-93.

Higgins, R.C. (2001). Analysis of Financial Management, $6^{\text {th }}$ edition. New York: McGraw-Hill.

Jordan, B.D., Miller, T.W. \& Dolvin, S.D. (2012). Fundamentals of Investments, $6^{\text {th }}$ edition. New York: McGraw-Hill.

Katchova, A.L. \& Enlow, S.J. (2013). Financial performance of publicly-traded Agribusinesses. Agricultural Finance Review, 73(1), pp. 58-73.

Kalluci, I. (2011). Analysis of the Albanian banking system in a risk-performance framework, Bank of Albania. (Working Paper)

Lovemore, F.C.H. \& Brummer, L.M. (2003). The ABC of financial management, $2^{\text {nd }}$ edition. Pretoria: Van Schaik Publishers. 
Patro, D.K., Wald, J.K. \& Wu, Y. (2002). The Impact of Macro-economic and Financial Variables on Market Risk: Evidence from International Equity Returns. European Financial Management, 8(4), pp. 421-447.

SARB. (2012). Interest rates and how they work. Pretoria: South African Reserve Bank.

Salehi, M. \& Derakhshan, M. (2012). A study of economic index effects on return on equity in Iranian companies. International Research Journal of Applied and Basic Sciences, 3(8), pp. 1691-1696.

Sharma, P. \& Gounder, N. (2011). Profitability determinants of deposit institutions in small, underdeveloped financial systems: the case of Fiji, Discussion Paper 2012-06. Brisbane: Griffith University.

Sheela, S.C. \& Karthikeyan, K. (2012). Financial Performance of Pharmaceutical Industry in India using DuPont Analysis. European Journal of Business and Management, 4(14), pp. 84-91.

Stambaugh, A.R. \& McGowan, C.B. (2012). Using Disaggregated Return on Assets to Conduct a Financial Analysis of a Commercial Bank Using an Extension of the DuPont System of Financial Analysis. Accounting and Finance Research, 1(1), pp. 152-161.

Vintila. G. \& Duca, F. (2012). The Impact of Financial Leverage to Profitability Study of Companies Listed in Bucharest Stock Exchange. Unpublished PhD thesis. Constanta: Ovidius University.

Ward, M. \& Price, A. (2006). Turning vision into value. Pretoria: Van Schaik Publishers. 